\title{
Pengaruh perubahan sudut camshaft terhadap performa mesin sepeda motor sebagai upaya efisiensi energi
}

\author{
Lukito Dwi Yuono1, Eko Budiyanto2* \\ 1,2Prodi Teknik Mesin, Universitas Muhammadiyah Metro \\ Jl. Ki Hajar Dewantara 15 A Kota Metro, Lampung, Indonesia \\ ${ }^{*}$ Corresponding author: eko_budiyanto99@yahoo.com
}

\begin{abstract}
The role of the camshaft (noken as) is very important, including determining the time to open the valve, regulating the length of the valve opening duration, determining the overlap inlet and exhaust valve duration, as well as being a major component of the engine's working system. Modification of the camshaft angle is expected to be able to increase the efficiency of the combustion of fuel entering the combustion chamber and increase compression pressure in the combustion chamber so that it can improve volume quality of fuel entering the combustion chamber and can provide greater power to the engine rotation when in use. The purpose of this study was to determine the effect of camshaft angle changes on motorcycle engine performance and determine the effect of the camshaft duration on fuel consumption. The method that will be used in this research is to provide variations in angular changes on the camshaft of $2^{0}, 4^{0}, 6^{0}$.Then test the dyno test on each variable. The result, the highest torque is the camshaft $4^{0}$ variation with a value of $8.25 \mathrm{Nm}$. The highest power is in variation 40 with the highest number of 8.76 PS. Acceleration with the fastest time is obtained in camshaft 40 variations with a time of 14.2 seconds at a speed of $100 \mathrm{~km} / \mathrm{h}$. As well as the most efficient fuel consumption is at variation $2^{0}$ with $150 \mathrm{ml}$ fuel consumption.
\end{abstract}

Keywords: Angle, camshaft, and engine performance.

\begin{abstract}
Abstrak
Peran dari camshaft (noken as) sangat penting, diantaranya menentukan waktu membuka katup, mengatur lamanya durasi pembukaan katup, menentukan lamanya durasi overlap katup masuk dan katup buang, serta merupakan komponen utama dari sistem kerja mesin. Modifikasi sudut camshaft diharapkan mampu meningkatkan efisiensi perpaduan bahan bakar yang masuk ke ruang bakar dan meningkatkan tekanan kompresi di ruang bakar sehingga dapat memperbaiki kualitas volume bahan bakar yang masuk ke ruang bakar dan dapat memberikan power yang lebih besar kepada putaran mesin saat digunakan. Tujuan penelitian ini adalah untuk engetahui pengaruh perubahan sudut camshaft terhadap kinerja mesin sepeda motor serta mengetahui pengaruh durasi camshaft terhadap konsumsi bahan bakar. Metode yang akan digunakan pada penelitian adalah dengan memberikan variasi perubahan sudut pada camshaft sebesar $2^{0}, 4^{0}, 6^{0}$. Kemudian melakukan uji dynotest pada masing masing variabel. Hasilnya, Torsi tertinggi adalah pada variasi camshaft $4^{0}$ dengan nilai $8,25 \mathrm{Nm}$. Daya tertinggi adalah pada variasi $4^{0}$ dengan angka tertinggi 8,76 PS. Akselerasi dengan waktu tercepat didapatkan pada variasi camshaft $4^{0}$ dengan waktu 14,2 detik pada kecepatan $100 \mathrm{~km} / \mathrm{h}$. Serta konsumsi bahan bakar yang paling hemat adalah pada variasi $2^{0}$ dengan konsumsi bahan bakar $150 \mathrm{ml}$.

Kata kunci: Sudut, camshaft, dan performa mesin.
\end{abstract}

\section{Pendahuluan}

Penggunaan kendaraan bermotor pada saat ini baik yang roda dua, roda empat, atau pun selebihnya sudah menjadi kebutuhan primer sehari-hari sebagai penunjang kemudahan dan kualitas hidup kebanyakan individu maupun kelompok. Penggunaan sehari-hari baik sebagai 
kendaraan pribadi ataupun industri harus ditunjang dengan performa yang baik, terutama mayoritas penduduk Indonesia golongan menengah ke bawah menggunakan kendaraan sepeda motor sebagai kebutuhan primer. Karena faktor harga dan kemudahan mendapatkannya dengan berbagai cara baik secara tunai ataupun kredit [1].

Penggunaan sehari-hari harus ditunjang dengan performa mesin yang optimal dengan perawatan berkala setiap berapa lama sekali sesuai anjuran. Namun terkadang banyak pula yang kurang puas dengan performa engine sepeda motor nya sehingga banyak melakukan perubahan ataupun modifikasi pada mesin terutama pada sistem bahan bakar dan volume yang di atur oleh camshaft (noken as) sehingga dipercaya dapat meningkatkan performa motor itu sendiri [2].

Noken as atau disebut kem atau camshfat adalah komponen yg terdapat pada mesin 4 tak yg berfungsi untuk mengatur dan menggerakkan katup/klep (valve) dengan cara mendorongnya dengan dua tonjolan (lift) [3].

Noken as digerakkan oleh timing chain, yang menghubungkannya dengan poros engkol. Peran vital noken as dalam performa motor 4 tak terletak pada fungsinya yang mengatur timing saat klep terbuka sehingga timing bahan bakar dan udara yg masuk ke head silinder tepat sesuai dengan langkah piston. Peran dari camshaft sangat penting, diantaranya menentukan waktu membuka katup, mengatur lamanya durasi pembukaan katup, menentukan lamanya durasi overlap katup masuk dan katup buang, serta merupakan komponen utama dari sistem kerja mesin [4].

Modifikasi sudut camshaft diharapkan mampu meningkatkan efisiensi perpaduan bahan bakar yang masuk ke ruang bakar dan meningkatkan tekanan kompresi di ruang bakar sehingga dapat memperbaiki kualitas volume bahan bakar yang masuk ke ruang bakar dan dapat memberikan power yang lebih besar kepada putaran mesin saat digunakan. Kualitas pembakaran yang baik dapat meningkatkan unjuk kerja pada engine [4]. Untuk itu, maka perlu dilakukan analisa pengaruh sudut camshaft terhadap kinerja mesin.

\section{Tinjauan Pustaka}

1. Prinsip kerja camshaft

Pada motor bensin empat langkah, bahan bakar masuk ke ruang silinder setelah di campur dengan udara di karburator atau throttlebody. Masuknya bahan bakar di atur oleh terbuka dan tertutup nya katup hisap dan katup buang. Katup ini terbuka dan tertutup karena kerja dari camshaft yang digerakkan oleh poros engkol (crank shaft). Mekanisme katupini dirancang sedemikian rupa sehingga camshaft berputar satu kali untuk menggerakkan katup hisap dan katup buang setiap dua kali berputarnya poros engkol.

Pada sebuah camshaft terdapat bagian-bagian yang masing-masing mempunyai peranan penting. Bagianbagian camshaft seperti valve lift (jarak angkat katup), valve lift duration (lama angkat katup), valve lift timing (waktu angkat katup), lobe separation angle (LSA) dan overlap akan mempengaruhi banyak sedikitnya campuran bahan bakar dan udara yang masuk ke dalam ruang bakar.

Pada saat bersambungnya akhir gerakan membuang akan dimulai gerakan menghisap, maka pada saat torak berada di TMA kedua katupnya berada dalam keadaan membuka. Keadaan dimana kedua katup terbuka secara bersamaan tersebut dinamakan overlap. Terbukanya katupkatup pada saat pemindahan gerakan dari gerakan kerja ke gerakan menghisap, supaya gas yang telah terbakar dapat keluar seluruhnya, sehingga pemasukan gas baru tidak bercampur dengan gas bekas di dalam silinder.

Melalui modifikasi camshaft maka dapat mengubah waktu membuka dan menutupnya katup. Tujuan akhir dalam modifikasi camshaft yaitu untuk merubah karakter tenaga dan torsi mesin. Diharapkan dengan berubahnya karakter 
tenaga dan torsi mesin dapat beroprasi lebih optimal di medan tertentu.

Putaran mesin akan mempengaruhi putaran camshaft, semakin tinggi putaran mesin akan mengakibatkan putaran camshaft semakin meningkat pula. Putaran camshaft yang semakin tinggi akan berdampak pada pembukaan dan penutupan katup yang semakin cepat. Dalam desain camshaft perlu diperhatikan penggunaan mesin, digunakan pada putaran mesin rendah atau pada putaran mesin tinggi.

Di dalam desain sebuah camshaft terdapat berbagai bagian yang memiliki fungsi sendiri-sendiri yang akan mempengaruhi variasi buka-tutup dari katup masuk dan buang.

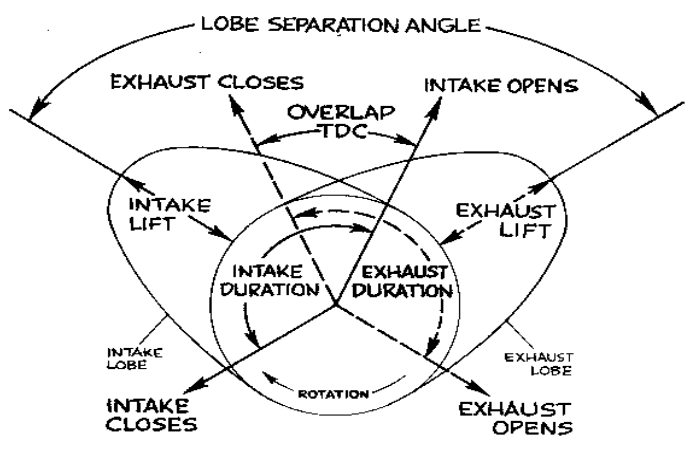

Gambar 1. Bagian-bagian camshaft

LSA berhubungan dengan overlap, LSA dengan overlap berbanding terbalik, dengan catatan duration tetap. Dengan memperbesar LSA sama dengan memperkecil overlap, sebaliknya menyempitkan LSA memperbesar overlap.

Pada saat bersambung nya akhir gerakan membuang akan dimulai gerakan mengisap, maka pada saat torak berada di TMA kedua katupnya berada dalam keadaan membuka. LSA pada camshaft Untuk mendapatkan torsi dan daya yang maksimal dapat dilihat dari tekanan kompresi yang dihasilkan, untuk mendapatkan tekanan kompresi yang tinggi, pembukaan katup isap (in open) di percepat sebelum titik matiatas (TMA) dan penutupan katup isap (inclose) diperlambat setelah titik mati bawah (TMB). LSA dan overlap saling berhubungan, dengan memperlebar LSA akan mengurangi jarak overlap dan sebaliknya jika mempersempit
LSA akan menambah jarak overlap dengan catatan lift duration yang digunakan tetap. Untuk mengetahui besarnya LSA harus mengetahui terlebih dahulu waktu pembukaan dan penutupan katup (in open, in close, ex open, ex close). Setelah diperoleh datanya dapat dicari besar LSA nya [5].

Tabel 1. Typical effect camshaft (Hammil, 1998)

\begin{tabular}{ll}
\hline Cam Change & Typical Effect \\
\hline Durasi Tinggi & $\begin{array}{l}\text { Menggeser rentang ke } \\
\text { putaran atas }\end{array}$ \\
\hline Durasi Rendah & $\begin{array}{l}\text { Menambah torsi putaran } \\
\text { bawah }\end{array}$ \\
\hline Overlaping Besar & $\begin{array}{l}\text { Meningkatkan bahan } \\
\text { bakar ke ruang bakar, } \\
\text { boros konsumsi bahan } \\
\text { bakar }\end{array}$ \\
\hline Overlaping Kecil & $\begin{array}{l}\text { Meningkatkan respon } \\
\text { pada putaran bawah. }\end{array}$ \\
\hline & $\begin{array}{l}\text { Powerband lebih } \\
\text { lebar, power } \\
\text { memuncak stasioner } \\
\text { lembut }\end{array}$ \\
\hline Menambah LSA & $\begin{array}{l}\text { Meningkatkan torsi } \\
\text { menengah, akselerasi } \\
\text { cepat, powerband lebih } \\
\text { sempit }\end{array}$ \\
\hline
\end{tabular}

2. Torsi dan daya

Torsi adalah gaya tekan putar pada bagian yang berputar, sepeda motor digerakkan oleh torsi yang disalurkan dari camshaft. Torsi dapat dicari dengan menggunakanj rumus:

Keterangan:

$$
T=F \times l(N . m)
$$

$\mathrm{T}=$ Torsi benda yang berputar (N.m)

$\mathrm{F} \quad=$ Gaya sentrifugal dan benda yang perputar $(\mathrm{N})$

$l=$ Jarak benda ke pusat rotasi $(\mathrm{m})$

Kerja rata-rata di ukur berdasarkan tenaga akhir (torsi dari camshaft menggerakkan sepeda motor tapi ini hanya gaya untuk menggerakkan sepeda motor dan kecepatan yang menggerakkan sepeda motor tidak di perhitungkan tenaga adalah kecepatan yang mana menimbulkan kerja.

$$
P=\frac{2 \pi n . T}{60} \quad[6]
$$


Keterangan:

$$
\begin{aligned}
& \mathrm{P}=\text { Daya (watt) } \\
& \mathrm{n}=\text { Putaran (1/sekon) } \\
& \mathrm{T}=\text { Torsi }
\end{aligned}
$$

\section{Metode Penelitian}

1. Variabel penelitian

Variabel yang digunakan dalam penelitian ini adalah sebagai berikut:

1) Variabel bebas. Variabel bebas adalah variabel yang besarannya ditentukan sebelum dilakukan dan tidak dipengaruhi variabel lain. Pada penelitian ini variabel bebasnya adalah sudut camshaft sebesar $2^{0}, 4^{0}$, dan $6^{0}$ dari nilai Yield Strength.

2) Variabel terikat. Variabel terikat adalah variabel yang besar nilainya tergantung pada variabel bebas dan nilainya diperoleh setelah pelaksanaan penelitian. Pada penelitian ini variabel terikatnya adalah Torsi, Daya, putaran maksimal dan konsumsi bahan bakar.

3) Variabel terkontrol. Variabel terkontrol adalah variabel yang besarannya dikendalikan atau dibuat tetap selama penelitian. Pada penelitian ini variabel terkontrolnya adalah jenis mesin sepeda motor dan bahan bakar.

2. Metode pengambilan data

Dalam penelitian ini data maupun informasi yang didapat diperoleh melalui beberapa metode yaitu:

1) Studi Pustaka

2) Observasi secara langsung

3) Pengujian

a. Waktu yang diperlukan untuk 3 kali sesi pengujian camshaft yang menggunakan perubahan sudut $2^{0}, 4^{0}$, dan $6^{0}$ di setiap sesi terhadap satu camshaft dilakukan 3 kali sesi jadi total dari 3 spesimen yang disediakan total akan melalui 9 kali pengujian di 3 sesi dan melihat peningkatan yang terjadi terhadap kinerja mesin. b. Uji akselerasi untuk mengetahui peningkatan kecepatan pada setiap camshaft yang disediakan dengan melihat kecepatan motor secara langsung ketika running di jalan dengan jarak tertentu.

c. Saat uji akselerasi, dilihat pula efisiensi bahan bakar yang digunakan di setiap penggunaan camshaft yang berbeda.

3. Waktu dan tempat penelitian

Penelitian dilakukan

di

Laboratorium Teknik Mesin Universitas Muhammadiyah Metro dan Bengkel MVK Racing, Way Kandis, Bandar Lampung pada bulan Januari-Maret 2020. Pada penelitian ini dikonsentrasikan pada modifikasi camshaft dengan melihat pengaruh pada mesin dan peningkatan Torsi, Daya, maupun kecepatan dari sepeda motor tersebut.

4. Alat dan bahan penelitian

1) Dynamometer Test (Dynotest),

2) Mesin bubut,

3) Mesin Sepeda Motor Honda Revo 2007 ,

4) Kunci pas dan ring lengkap,

5) Stopwatch,

6) Gelas ukur,

7) Camshaft dan BBM pertamax.

5. Prosedur penelitian

Prosedur pengujian melalui beberapa tahapan seperti berikut:

1) Menyiapan alat bahan yang akan diperlukan untuk proses penelitian,

2) Melakukan proses pembubutan pada komponen 3 camshaft dengan merubah sudutnya menjadi $2^{0}, 4^{0}$, dan $6^{0}$.

3) Memasang camshaft yang sudah dimodifikasi dengan sudut $2^{0}$ pada mesin sepeda motor lalu dan ditempatkan pada alat dynotest,

4) Mengisi tangki BBM pada mesin sepeda motor dengan takaran 1 liter,

5) Menghidupkan mesin dan melakukan pengujian,

6) Data yang akan diperoleh dari uji dynotest adalah Torsi, Daya, dan 
putaran maksimal, sedangkan konsumsi BBM dilakukan dengan cara menakar BBM yang terpakai dalam waktu yang sama selama pengujian,

7) Melakukan pengujian pada masingmasing camshaft dengan cara yang sama.

\section{Hasil dan Pembahasan}

Tabel 2 berikut hasil pemeriksaan dan pengamatan pada komponen cylinder head (mekanisme katup) pada perangkatperangkat standar selain variasi camshaft.

Tabel 2. Hasil identifikasi mekanisme katup

\begin{tabular}{llll}
\hline No & \multicolumn{1}{c}{$\begin{array}{c}\text { Nama } \\
\text { Komponen }\end{array}$} & $\begin{array}{c}\text { Stand } \\
\text { ar } \\
(\mathrm{mm})\end{array}$ & $\begin{array}{c}\text { Hasil } \\
\text { ukur } \\
(\mathrm{mm})\end{array}$ \\
\hline 1 & $\begin{array}{l}\text { Panjang pegas } \\
\text { katup IN }\end{array}$ & 34,30 & 34,30 \\
\hline 2 & $\begin{array}{l}\text { Panjang pegas } \\
\text { katup EX }\end{array}$ & 34,30 & 34,30 \\
\hline 3 & $\begin{array}{l}\text { Diameter } \\
\text { payung klep IN }\end{array}$ & 21 & 21 \\
\hline 4 & $\begin{array}{l}\text { Diameter } \\
\text { payung klep EX }\end{array}$ & 19 & 19 \\
\hline 5 & $\begin{array}{l}\text { Diameter batang } \\
\text { klep }\end{array}$ & 5 & 5 \\
\hline
\end{tabular}

Dari hasil pemeriksaan komponen pada mekanisme katup komponen masih sesuai spesifikasi atandar, kecuali katup IN (valve Intake) dan EX (valve Exhaust) kebocoran katup ini dapat menyebabkan proses pembakaran menjadi tidak sempurna, dikarenakan campuran bahan bakar dan udara sebagian terbuang keluar. Sehingga menyebabkan tenaga pada kendaraan sepeda motor menjadi kurang maksimal. Penanganan pada kejadian seperti itu dapat diatasi dengan melakukan pengamplasan katup menggunakan Amril (grinding paste). Grinding paste pada dunia otomotif adalah serbuk atau gram dari bahan logam yang dicampur dengan sebuah pasta atau gel berminyak yang digunakan untuk mengamplas katup, baik katup Intake maupun Exhaust.
Tabel 3 berikut adalah tabel hasil pemeriksaan dan pengukuran piston dan silinder.

Tabel 3. Hasil Identifikasi komponen

\begin{tabular}{|c|c|c|c|}
\hline $\begin{array}{c}\text { Nama } \\
\text { Perangkat }\end{array}$ & $\begin{array}{c}\text { Panjang } \\
(\mathrm{mm})\end{array}$ & $\begin{array}{l}\text { Diameter } \\
(\mathrm{mm})\end{array}$ & Keterangan \\
\hline Piston & - & 50 & \\
\hline Silinder & - & 50 & $\begin{array}{l}\text { Sudah oversize } \\
100, \text { jadi } \\
\text { perubahan } 51\end{array}$ \\
\hline $\begin{array}{l}\text { Conecting } \\
\text { rod } \\
\text { (Stang } \\
\text { Seher) }\end{array}$ & 97 & 30 dan 13 & $\begin{array}{l}\text { Diameter } 30 \\
\text { yang terhubung } \\
\text { ke poros } \\
3 \text { engkol, } \\
\text { diameter } 13 \\
\text { yang terhubung } \\
\text { ke piston. }\end{array}$ \\
\hline
\end{tabular}

Diameter silinder standar yang digunakan adalah $50 \mathrm{~mm}$ dengan ketebalan mencapai $4 \mathrm{~mm}$ dan sudah mengalami oversize 100. Oversize sendiri bisa menggunakan 25, 50, 75, 100 dalam satuan milimeter seperti contoh diameter piston adalah 50 dan boring mengalami oversize 25, maka piston akan menjadi 50,25 mm. Sedangkan conecting rod standar panjang nya adalah $97 \mathrm{~mm}$ dengan diameter lingkaran 30 yang terhubung ke poros engkol (crank shaft) dan diameter 13 yang terhubung ke piston.

Berdasarkan uji dynotest yang telah dilakukan di MVK Racing Way Kandis Bandar Lampung didapatkan hasil pengujian dynotest yang menampilkan torsi, daya, dan putaran puncak Honda Revo 100 cc.

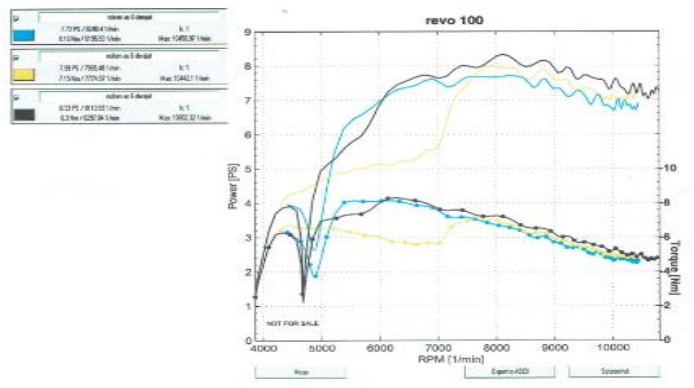

Gambar 2. Grafik dynotest camshaft sudut $6^{0}$ (modifikasi) 
Tabel 4. Hasil uji dynotest camshaft sudut $6^{0}$

\begin{tabular}{llll}
\hline $\begin{array}{c}\text { Sesi } \\
\text { Pengujian }\end{array}$ & $\begin{array}{c}\text { Torsi } \\
(\mathrm{Nm})\end{array}$ & $\begin{array}{c}\text { Daya } \\
(\mathrm{PS})\end{array}$ & $\begin{array}{c}\text { Putaran } \\
\text { maks.(rpm) }\end{array}$ \\
\hline Sesi 1 & 8,16 & 7,72 & 10450.97 \\
\hline Sesi 2 & 7,15 & 7,99 & 10442.1 \\
\hline Sesi 3 & 8,3 & 8,33 & 10802.32 \\
\hline
\end{tabular}

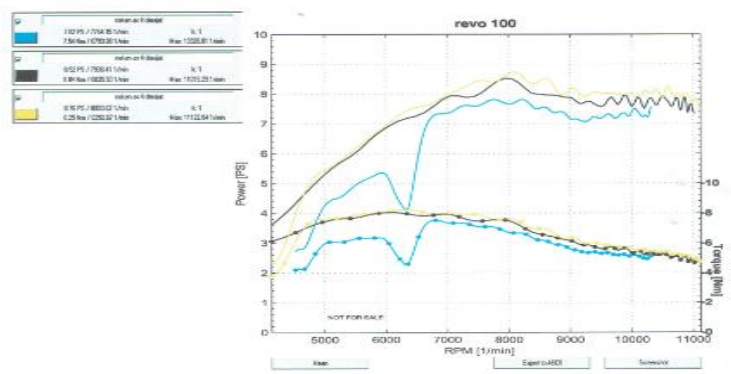

Gambar 3. Grafik dynotest camshaft sudut $4^{0}$ (racing harian)

Tabel 5. Hasil uji dynotest camshaft sudut $4^{0}$

\begin{tabular}{llll}
\hline $\begin{array}{c}\text { Sesi } \\
\text { Pengujian }\end{array}$ & $\begin{array}{c}\text { Torsi } \\
(\mathrm{Nm})\end{array}$ & $\begin{array}{c}\text { Daya } \\
(\mathrm{PS})\end{array}$ & $\begin{array}{c}\text { Putaran } \\
\text { maks.(rpm) }\end{array}$ \\
\hline Sesi 1 & 7,54 & 7,82 & 10328.81 \\
\hline Sesi 2 & 8,04 & 8,52 & 11019.29 \\
\hline Sesi 3 & 8,25 & 8,76 & 11122.64 \\
\hline
\end{tabular}

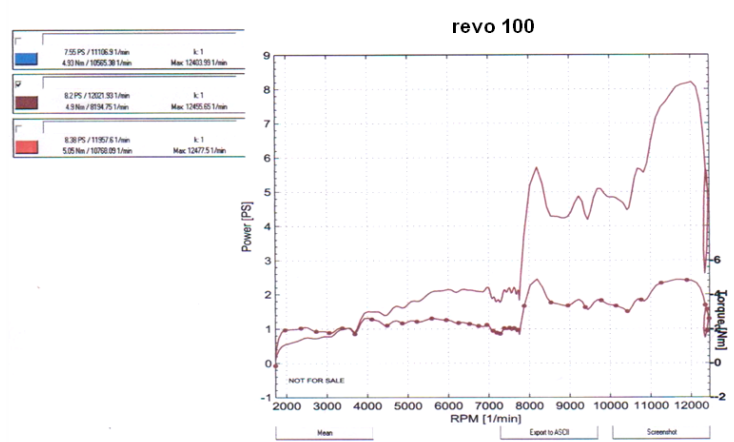

Gambar 4. Grafik dynotest camshaft sudut $2^{0}$ (standar)

Tabel 6. Hasil uji dynotest camshaft sudut $2^{0}$ (standar)

\begin{tabular}{llll}
\hline $\begin{array}{l}\text { Sesi } \\
\text { pengujian }\end{array}$ & $\begin{array}{l}\text { Torsi } \\
(\mathrm{Nm})\end{array}$ & $\begin{array}{l}\text { Daya } \\
(\mathrm{PS})\end{array}$ & $\begin{array}{l}\text { Putaran } \\
\text { maks.(rpm) }\end{array}$ \\
\hline Sesi 1 & 4,93 & 7,55 & 12403.99 \\
\hline Sesi 2 & 4,9 & 8,2 & 12455.65 \\
\hline Sesi 3 & 5,05 & 8,38 & 12477.5 \\
\hline
\end{tabular}

Pengujian akselerasi dilakukan dengan menguji langsung sepeda motor dengan menggunakan perlengkapan keamanan yang sesuai dengan safety riding yang ada dan kondisi jalan yang sepi. Pengujian dilakukan sebanyak 3 kali pengulangan. Adapun data yang diperoleh ditunjukkan pada Tabel 7.

Tabel 7. Hasil pengujian akselerasi

\begin{tabular}{|c|c|c|c|c|c|}
\hline $\begin{array}{l}\mathrm{N} \\
\mathrm{O}\end{array}$ & $\begin{array}{c}\text { Camsh } \\
\text { aft }\end{array}$ & $\begin{array}{c}\text { Jara } \\
\mathrm{k} \\
(\mathrm{m}) \\
\end{array}$ & $\begin{array}{c}\text { Kecepat } \\
\text { an awal } \\
(\mathrm{km} / \mathrm{h})\end{array}$ & $\begin{array}{l}\text { Kecepat } \\
\text { an akhir } \\
(\mathrm{km} / \mathrm{h})\end{array}$ & $\begin{array}{l}\text { Wak } \\
\text { tu (s) }\end{array}$ \\
\hline \multirow[t]{3}{*}{1} & \multirow[t]{3}{*}{$6^{0}$} & \multirow[t]{3}{*}{250} & 0 & 90 & 16,3 \\
\hline & & & 0 & 100 & 16,2 \\
\hline & & & 0 & 80 & 16,6 \\
\hline \multirow[t]{3}{*}{2} & \multirow[t]{3}{*}{$4^{0}$} & \multirow[t]{3}{*}{250} & 0 & 90 & 14,5 \\
\hline & & & 0 & 100 & 14,2 \\
\hline & & & 0 & 90 & 14,4 \\
\hline \multirow[t]{3}{*}{3} & \multirow[t]{3}{*}{$2^{0}$} & \multirow[t]{3}{*}{250} & 0 & 90 & 17,6 \\
\hline & & & 0 & 100 & 17,4 \\
\hline & & & 0 & 100 & 17,7 \\
\hline
\end{tabular}

Untuk konsumsi bahan bakar dilihat dari 3 variasi camshaft yang disediakan. Motor yang telah menggunakan bahan bakar pertamax 92 dengan 3 variasi camshaft akan menempuh jarak 1 kilometer dengan kecepatan tetap $80 \mathrm{~km} / \mathrm{h}$ dengan percobaan 3 kali putaran bolak-balik untuk mencari nilai rata-rata. Adapun data yang diperoleh ditunjukkan pada Tabel 8.

Tabel 8. Konsumsi bahan bakar

\begin{tabular}{|c|c|c|c|}
\hline \multirow{2}{*}{$\begin{array}{c}\text { Jarak } \\
\text { tempuh dan } \\
\text { kecepatan } \\
\text { tetap }\end{array}$} & \multicolumn{3}{|c|}{$\begin{array}{l}\text { Konsumsi bahan bakar } \\
(\mathrm{ml})\end{array}$} \\
\hline & $2^{0}$ & $4^{0}$ & $6^{0}$ \\
\hline \multirow{3}{*}{$\begin{array}{c}1 \mathrm{~km} \\
80 \mathrm{~km} / \mathrm{h}\end{array}$} & 150 & 100 & 200 \\
\hline & 150 & 200 & 300 \\
\hline & 150 & 200 & 250 \\
\hline Rata-rata & 150 & 166,6 & 250 \\
\hline
\end{tabular}

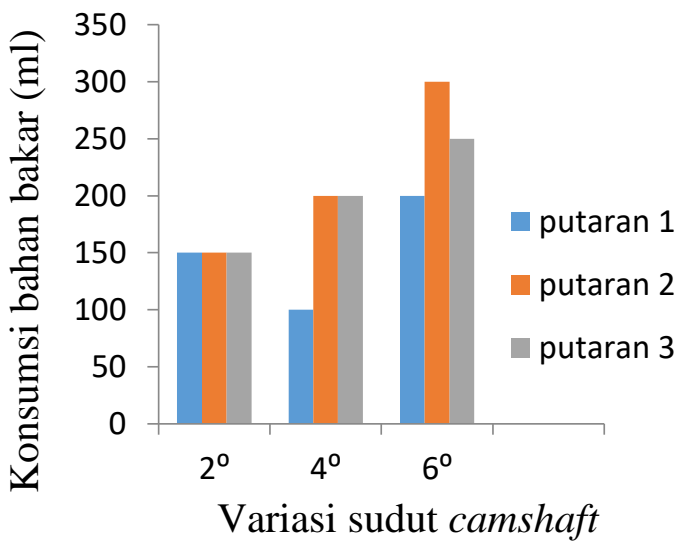

Gambar 5. Grafik konsumsi bahan bakar

Akselerasi (a) adalah percepatan atau perubahan kecepatan setiap waktu. 
Pada kenyataannya, kecepatan benda bergerak tidak selalu tepat. Artinya, kecepatan selalu berubah, berubahnya percepatan inilah yang dinamakan akselerasi. Untuk menghitung akselerasi digunakan persamaan sebagai berikut.

$$
a=\frac{\Delta V}{t}
$$

Sehingga untuk akselerasi sepeda motor setelah dilakukan perhitungan didapatkan nilai akselerasi seperti ditunjukkan pada Tabel 9.

Tabel 9. Nilai akselerasi hasil perhitungan

\begin{tabular}{|c|c|c|c|c|c|c|}
\hline $\begin{array}{l}\mathrm{N} \\
\mathrm{o}\end{array}$ & $\begin{array}{c}\text { Sud } \\
\text { ut }\end{array}$ & $\begin{array}{c}\text { Kecepa } \\
\text { tan } \\
\text { awal } \\
(\mathrm{m} / \mathrm{s})\end{array}$ & $\begin{array}{c}\text { Kecepata } \\
\text { n akhir } \\
(\mathrm{m} / \mathrm{s})\end{array}$ & $\begin{array}{c}\text { Waktu } \\
\text { (s) }\end{array}$ & $a\left(\mathrm{~m} / \mathrm{s}^{2}\right)$ & $\begin{array}{l}a \text { rata- } \\
\text { rata } \\
\left(\mathrm{m} / \mathrm{s}^{2}\right)\end{array}$ \\
\hline 1 & \multirow{3}{*}{$6^{0}$} & 0 & 25 & 16,3 & 1,533 & \multirow{3}{*}{1,528} \\
\hline 2 & & 0 & 27,7778 & 16,2 & 1,714 & \\
\hline 3 & & 0 & 22,22 & 16,6 & 1,338 & \\
\hline 4 & \multirow{3}{*}{$4^{0}$} & 0 & 25 & 14,5 & 1,724 & \multirow{3}{*}{1,605} \\
\hline 5 & & 0 & 27,7778 & 14,2 & 1,956 & \\
\hline 6 & & 0 & 25 & 14,4 & 1,736 & \\
\hline 7 & \multirow{3}{*}{$2^{0}$} & 0 & 25 & 17,6 & 1,420 & \multirow{3}{*}{1,528} \\
\hline 8 & & 0 & 27,7778 & 17,4 & 1,596 & \\
\hline 9 & & 0 & 27,7778 & 17,7 & 1,569 & \\
\hline
\end{tabular}

Perhitungan pemakaian bahan bakar dilakukan dengan menggunakan gelas ukur dengan kapasitas tertentu. Pada gelas ukur diketahui jumlah pemakaian bahan bakar yang digunakan dalam pengujian dengan kapasitas gelas ukur adalah $250 \mathrm{ml}$ yang dikonversikan menjadi $0,00025 \mathrm{~m}^{3}$. Dalam konsumsi bahan bakar yang diuji dapat diketahui waktu yang dibutuhkan dengan menggunakan stopwatch. Rumus yang digunakan adalah sebagai berikut :

Keterangan :

$$
\mathrm{V}(b f c)=\frac{3600 . \mathrm{Vg}}{t}
$$

$\mathrm{V}(b f c)$ : Konsumsi bahan bakar

Vg : Volume gelas ukur

$\mathrm{t} \quad$ : waktu yang dibutuhkan

Pemakaian bahan bakar pada variasi camshaft $6^{0}$ dihitung dengan perhitungan sebagai berikut :

1. $\mathrm{V}(b f c)=\frac{3600.0,00025 \mathrm{~m}^{3}}{16,3 \mathrm{~s}}=0,055 \mathrm{~m}^{3} / \mathrm{jam}$

2. $\mathrm{V}(b f c)=\frac{3600.0,00025 \mathrm{~m}^{3}}{16,2 \mathrm{~s}}=0,56 \mathrm{~m}^{3} / \mathrm{jam}$

3. $\mathrm{V}(b f c)=\frac{3600.0,00025 \mathrm{~m}^{3}}{16,6 \mathrm{~s}}=0,054 \mathrm{~m}^{3} / \mathrm{jam}$

Pemakaian bahan bakar pada variasi camshaft $4^{0}$ dihitung dengan perhitungan sebagai berikut :
1. $\mathrm{V}(b f c)=\frac{3600.0,00025 \mathrm{~m}^{3}}{14,5 \mathrm{~s}}=0,0620 \mathrm{~m}^{3} / \mathrm{jam}$

2. $\mathrm{V}(b f c)=\frac{3600.0,00025 \mathrm{~m}^{3}}{14,2 \mathrm{~s}}=0,063 \mathrm{~m}^{3} / \mathrm{jam}$

3. $\mathrm{V}(b f c)=\frac{3600.0,00025 \mathrm{~m}^{3}}{14,4 \mathrm{~s}}=0,0625 \mathrm{~m}^{3} / \mathrm{jam}$

Pemakaian bahan bakar pada variasi camshaft $2^{0}$ dihitung dengan perhitungan sebagai berikut :

1. $\mathrm{V}(b f c)=\frac{3600.0,00025 \mathrm{~m}^{3}}{17,6 \mathrm{~s}}=0,0511 \mathrm{~m}^{3} / \mathrm{jam}$

2. $\mathrm{V}(b f c)=\frac{3600.0,00025 \mathrm{~m}^{3}}{17,4 \mathrm{~s}}=0,0517 \mathrm{~m}^{3} / \mathrm{jam}$

3. $\mathrm{V}(b f c)=\frac{3600.0,00025 \mathrm{~m}^{3}}{17,7 \mathrm{~s}}=0,0508 \mathrm{~m}^{3} / \mathrm{jam}$

Konsumsi bahan bakar spesifik sendiri perlu di dapat kan untuk mengetahui seberapa besar konsumsi bahan bakar yang lebih spesifik, dapat di hitung dengan rumus sebagai berikut :

$$
S f c=\frac{V}{P}
$$

Keterangan :

Sfc : Konsumsi bahan bakar spesifik $\left(\mathrm{m}^{3} / \mathrm{kW}\right.$.jam $)$

$\mathrm{V} \quad$ : Konsumsi bahan bakar $\left(\mathrm{m}^{3} / \mathrm{jam}\right)$

P : Daya $(\mathrm{kW})$

Pada variasi camshaft $6^{0}$ konsumsi

bahan bakar spesifik yang didapat adalah :

1. $S f C=\frac{0,055 \frac{\mathrm{m}^{3}}{j a m}}{5,71 \mathrm{kw}}$

$=0,00963 \mathrm{~m}^{3} / \mathrm{kW} . \mathrm{jam}$

2. $S f C=\frac{0,56 \frac{\mathrm{m}^{3}}{\mathrm{jam}}}{5,91 \mathrm{kw}}$

$=0,0947 \mathrm{~m}^{3} / \mathrm{kW} . \mathrm{jam}$

3. $S f C=\frac{0,054 \frac{\mathrm{m}^{3}}{\mathrm{jam}}}{6,16 \mathrm{kw}}$

$$
=0,00325 \mathrm{~m}^{3} / \mathrm{kW} . \mathrm{jam}
$$

Pada variasi camshaft $4^{0}$ konsumsi

bahan bakar spesifik yang di dapat adalah :

1. $S f c=\frac{0,0620 \frac{\mathrm{m}^{3}}{j a m}}{5,78 \mathrm{kw}}$

$=0,0107 \mathrm{~m}^{3} / \mathrm{kW} . \mathrm{jam}$

2. $S f C=\frac{0,063 \frac{\mathrm{m}^{3}}{\mathrm{jam}}}{6,30 \mathrm{kw}}$

$=0,01 \mathrm{~m}^{3} / \mathrm{kW} . \mathrm{jam}$

3. $S f c=\frac{0,0625 \frac{\mathrm{m}^{3}}{j a m}}{6,48 \mathrm{kw}}$

$=0,0096 \mathrm{~m}^{3} / \mathrm{kW} . \mathrm{jam}$

Pada variasi camshaft $2^{0}$ konsumsi

bahan bakar spesifik yang didapat adalah :

1. $S f C=\frac{0,0511 \frac{\mathrm{m}^{3}}{\mathrm{jam}}}{5,58 \mathrm{kw}}$ 
$=0,0091 \mathrm{~m}^{3} / \mathrm{kW} . \mathrm{jam}$

2. $S f C=\frac{0,0517 \frac{\mathrm{m}^{3}}{\mathrm{jam}}}{6,06 \mathrm{kw}}$

$=0,0085 \mathrm{~m}^{3} / \mathrm{kW} . \mathrm{jam}$

3. $S f C=\frac{0,0508 \frac{\mathrm{m}^{3}}{\mathrm{jam}}}{6,20 \mathrm{kw}}$

$=0,0081 \mathrm{~m}^{3} / \mathrm{kW} . \mathrm{jam}$

Berdasarkan pengujian dynotest, nilai Torsi pada variasi $6^{0}$ adalah pada putaran pertama mencapai $8,16 \mathrm{Nm}$, pada putaran kedua mencapai $7,15 \mathrm{Nm}$, dan pada putaran ke tiga mencapai $8,3 \mathrm{Nm}$. Kemudian pada variasi $4^{0}$ adalah pada putaran pertama $7,54 \mathrm{Nm}$, pada putaran ke dua 8,04 Nm, dan pada putaran ketiga mencapai 8,25 Nm. Kemudian pada variasi $2^{0}$ pada putaran pertama mencapai 4,93 $\mathrm{Nm}$, kemudian pada putaran kedua mencapai 4,9 Nm dan pada putaran ketiga mencapai 5,05 Nm.

Selanjutnya nilai Daya yang dihasilkan dari perubahan sudut camshaft pada variasi $6^{0}$ pada putaran pertama mencapai 7,72 PS, pada putaran kedua mencapai 7,99 PS, dan pada putaran ketiga mencapai 8,33 PS. Kemudian pada variasi $4^{0}$ pada putaran pertama mencapai 7,82 $\mathrm{PS}$, kemudian pada putaran kedua mencapai 8,52 PS, pada putaran ke tiga mencapai 8,76 PS. Kemudian pada variasi $2^{0}$ pada putaran pertama mencapai 7,55 PS, kemudian pada putaran kedua mencapai 8,2 PS, dan pada putaran ketiga mencapai 8,38 PS.

Pengujian Konsumsi bahan bakar pada 3 variasi camshaft tersebut ditempuh dengan jarak 1 kilometer dengan kecepatan tetap $80 \mathrm{~km} / \mathrm{h}$ didapatkan pada variasi $6^{0}$ pada putaran pertama adalah $200 \mathrm{ml}$, pada putaran kedua $300 \mathrm{ml}$, dan pada putaran ketiga $250 \mathrm{ml}$ dengan rata-rata konsumsi bahan bakar pada variasi camshaft $6^{0}$ adalah $250 \mathrm{ml}$. Pada variasi $4^{0}$ pada putaran pertama adalah $100 \mathrm{ml}$, pada putaran kedua adalah $200 \mathrm{ml}$, dan pada putaran ketiga adalah $200 \mathrm{ml}$ dengan rata-rata konsumsi bahan bakar pada variasi camshaft $4^{0}$ adalah 166,6 ml. Pada variasi camshaft $2^{0}$ pada putaran pertama, kedua, dan ketiga didapat konsumsi bahan bakar yang sama yaitu $150 \mathrm{ml}$ dan nilai rata-rata $150 \mathrm{ml}$.

\section{Kesimpulan}

Torsi yang didapatkan setelah dilakukannnya pengujian dynotest yang tertinggi adalah pada variasi camshaft $4^{0}$ dengan nilai $8,25 \mathrm{Nm}$ pada sesi ketiga pengujian, dan angka terendah pada variasi $2^{0}$ dengan angka 4,9 $\mathrm{Nm}$. Daya yang didapatkan setelah dilakukannya pengujian dynotest yang tertinggi adalah pada variasi $4^{0}$ dengan angka tertinggi 8,76 PS pada sesi ketiga pengujian, dan angka terendah pada variasi $2^{0}$ dengan angka 7,55 PS. Akselerasi sepeda motor setelah menggunakan variasi camshaft dengan jarak tempuh 250 meter waktu tercepat didapatkan pada variasi camshaft $4^{0}$ dengan waktu 14,2 detik pada kecepatan $100 \mathrm{~km} / \mathrm{h}$ padapada putaran kedua, dan waktu terlambat pada penggunaan variasi $2^{0}$ dengan waktu 17,7 detik pada kecepatan 100 km/h. Konsumsi bahan bakar setelah menggunakan variasi camshaft dengan jarak tempuh 1 kilometer dengan kecepatan tetap $80 \mathrm{~km} / \mathrm{h}$ adalah yang paling hemat pada variasi $2^{0}$ dengan konsumsi bahan bakar $150 \mathrm{ml}$, dan yang terboros adalah pada variasi $6^{0}$ dengan 300 ml pada putaran kedua.

\section{Referensi}

[1]. Aprianti, E. (2017). Analisis SWOT dalam menentukan strategi pemasaran sepeda motor Honda (studi pada PT. Pasific Motor 1 Cikarang).

[2]. Siswanto, Y. D. (2012). Pengaruh Variasi Lobe Separation Angle Camshaft dan Variasi Putaran Mesin Terhadap Daya Pada Sepeda Motor Honda Supra X 125 Tahun 2008. Jurnal Nosel, 1(1).

[3]. Mulyono, M. (2013). Analisis pemotongan ramp poros bubungan terhadap konsumsi bahan bakar dan emisi gas buang pada Suzuki Shogun 125 SP tahun 2005. Jurnal Nosel, 1(3). 
[4]. Stevansa, P. A. (2014). Pengaruh Penggunaan Camshaft Standard dan Camshaft Racing Terhadap Unjuk Kerja Motor Bensin Empat Langkah (Doctoral dissertation, Universitas Muhammadiyah Surakarta).

[5]. Pambudi, A. T. S. (2019). Optimasi camshaft dengan variasi tinggi lift pada mesin (x) 100cc menggunakan mesin modifikasi camshaft (Doctoral dissertation, Institut Teknologi Nasional Malang).

[6]. Simbolon, E., Nasution, A. H., Sitorus, T. B., Pintoro, A., \& Ambarita, H. (2015). Kajian performansi torsi dan konsumsi bahan bakar (SFC) mesin genset otto satu silinder dengan bahan bakar campuran premium dan super fuel. Jurnal Dinamis, 3(1).

[7]. Putra, F. S., Sanata, A., \& Muttaqin, A. Z. Pengaruh Variasi Durasi Camshaft Terhadap Unjuk Kerja Motor Bakar 4 Langkah. 